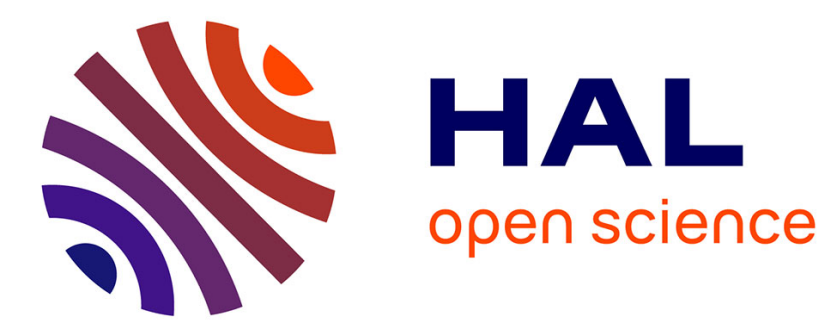

\title{
Neutron-based computed microtomography: Pliobates cataloniae and Barberapithecus huerzeleri as a test-case study
}

\author{
Alessandro Urciuoli, Clément Zanolli, Josep Fortuny, Sergio Almécija, \\ Burkhard Schillinger, Salvador Moyà-Solà, David Alba
}

\section{To cite this version:}

Alessandro Urciuoli, Clément Zanolli, Josep Fortuny, Sergio Almécija, Burkhard Schillinger, et al.. Neutron-based computed microtomography: Pliobates cataloniae and Barberapithecus huerzeleri as a test-case study. American Journal of Physical Anthropology, 2018, 166 (4), pp.987-993. 10.1002/ajpa.23467 . hal-02296685

\section{HAL Id: hal-02296685 \\ https://hal.science/hal-02296685}

Submitted on 25 Feb 2021

HAL is a multi-disciplinary open access archive for the deposit and dissemination of scientific research documents, whether they are published or not. The documents may come from teaching and research institutions in France or abroad, or from public or private research centers.
L'archive ouverte pluridisciplinaire HAL, est destinée au dépôt et à la diffusion de documents scientifiques de niveau recherche, publiés ou non, émanant des établissements d'enseignement et de recherche français ou étrangers, des laboratoires publics ou privés. 
1 Neutron-based computed microtomography: Pliobates cataloniae and

Barberapithecus huerzeleri as a test-case study

\section{Alessandro Urciuoli ${ }^{1}$ | Clément Zanolli ${ }^{2}$ | Josep Fortuny ${ }^{3,1}$ | Sergio Almécija ${ }^{4,1}$ |}

\section{Burkhard Schillinger $^{5}$ | Salvador Moyà-Solà ${ }^{1,6,7}$ | David M. Alba ${ }^{1}$}

${ }^{1}$ Institut Català de Paleontologia Miquel Crusafont, Universitat Autònoma de Barcelona, Edifici ICTA-ICP, c/ Columnes s/n, Campus de la UAB, 08193 Cerdanyola del Vallès, Barcelona, Spain

²Laboratoire AMIS, UMR 5288 CNRS, Université Toulouse III Paul Sabatier, Toulouse,

France

${ }^{3}$ Centre de Recherches en Paléobiodiversité et Paléoenvironnements, Muséum National d'Histoire Naturelle, Bâtiment de Paléontologie, CP38, 8 rue Buffon, 75005 Paris, France ${ }^{4}$ Center for the Advanced Study of Human Paleobiology, Department of Anthropology, The George Washington University, Washington, DC 20052, USA

${ }^{5}$ Technische Universität München, Fakultat für Physik E21, James-Franck-Str.1, D-85747

Garching, Germany

${ }^{6}$ Institució Catalana de Recerca i Estudis Avançats, Pg. Lluís Companys 23, 08010,

Barcelona, Spain

${ }^{7}$ Unitat d'Antropologia (Departament de Biologia Animal, Biologia Vegetal i Ecologia),

Universitat Autònoma de Barcelona, 08193 Cerdanyola del Vallès, Barcelona, Spain

Number of text pages: 15

Number of figures: 3

Number of tables: 1

Abbreviated title: Neutron- $\mu \mathrm{CT}$ in paleoanthropology 
KEYWORDS

X-rays, neutron radiation, neutron imaging, fossil catarrhines

Correspondence: David M. Alba, Institut Català de Paleontologia Miquel Crusafont, Universitat Autònoma de Barcelona, Edifici ICTA-ICP, c/ Columnes s/n, Campus de la UAB, 08193 Cerdanyola del Vallès, Barcelona, Spain. +34 5868304. Email:

\section{david.alba@icp.cat}

Funding information: Spanish MINECO/FEDER EU, Project number: CGL2014-54373-P; Spanish AEI/FEDER EU, Project number: CGL2016-76431-P; Generalitat de Catalunya, CERCA Programme.

\section{Abstract}

Objectives: High-resolution imaging of fossils with X-ray computed microtomography $(\mu \mathrm{CT})$ has become a very powerful tool in paleontological research. However, fossilized bone, embedding matrix, and dental tissues do not always provide a distinct structural signal with X-rays. Here we report on neutron radiation as an alternative to standard Xrays for the $\mu \mathrm{CT}$ of 'problematic' fossils.

Materials and Methods: We compare neutron with X-ray $\mu \mathrm{CT}$ scans of fossils from two Miocene catarrhines from the Vallès-Penedès Basin: the cranium (IPS58443.1, holotype) of the putative stem hominoid Pliobates cataloniae, to discriminate between bone and matrix; and two lower molars (IPS1724n,o, holotype) of Barberapithecus huerzeleri, to discriminate among dental tissues.

Results: X-ray $\mu \mathrm{CT}$ scans of these specimens fail to retrieve any contrast between matrix/bone and enamel/dentine, whereas neutron $\mu \mathrm{CT}$ scans deliver high-contrast images, enabling a proper evaluation of the specimens' internal anatomy. 
Discussion: Low bone/matrix intensity difference with X-ray $\mu$ CT scans in IPS58443.1 is due to the extreme similarity in chemical composition between the matrix and the fossilized tissues, and the presence of high-density elements. In IPS1724, it is attributable to the convergence of enamel and dentine compositions during fossilization. On the contrary, neutron radiation returns very different contrasts for different isotopes of the same element and easily penetrates most metals. Neutron-based $\mu \mathrm{CT}$ scans therefore enable a correct definition of the bone/sediment and enamel/dentine interfaces, and hence a better segmentation of the images stack. We conclude that neutron radiation represents a successful alternative for high-resolution $\mu \mathrm{CT}$ of small-sized fossils that are problematic with standard X-rays.

\section{1 | INTRODUCTION}

The use of computed microtomography $(\mu \mathrm{CT})$ in paleontological research has dramatically increased during the last decade, in parallel to concomitant enhancements in image detectors and computing power. The success of computed tomography in paleontology is due to the fact that it enables the non-destructive study of internal anatomy, the virtual extraction of sediment-embedded fossils, the virtual reconstruction of damaged specimens (including the mirroring of antimeres), and even the retrodeformation of plastically deformed fossils (Macchiarelli et al., 2004; Olejniczak \& Grine, 2006; Olejniczak, Tafforeau, Temming, Smith, \& Hublin, 2007; Abel, Rettondini Laurini, \& Richter, 2012; Benazzi, Kullmer, Schulz, Gruppioni, \& Weber, 2013; Faulwetter, Vasileiadou, Kouratoras, Dailianis, \& Arvanitidis, 2013; Macchiarelli, Bayle, Bondioli, Mazurier, \& Zanolli, 2013;

Benazzi, Gruppioni, Strait, \& Hublin, 2014; Cunningham, Rahman, Lautenschlager, Rayfield, \& Donoghue, 2014; Lautenschlager, 2016). Modern X-ray $\mu C T$ (especially based on synchrotron radiation) can reach a very high spatial resolution (up to less than $1 \mu \mathrm{m}$; 
Gren et al., 2016), and the size of the specimens that can be scanned with a single acquisition has recently increased considerably (currently in the order of some decimeters; e.g., Tuniz et al., 2013).

Depending on the taphonomic processes occurring during fossilization, not all vertebrate fossil remains are amenable to internal anatomy analysis based on standard Xray $\mu \mathrm{CT}$. The latter may fail to retrieve an adequate contrast between the fossil bone and the matrix or between different dental tissues because of two main problems: (1) the embedding matrix and the fossilized tissues have a very similar composition, due to element exchange resulting from permineralization (Zanolli, Grine, Kullmer, Schrenk, \& Macchiarelli, 2015; Beaudet et al., 2016); (2) a considerable amount of high-density elements is present in the embedding sediment or in the fossil itself (Spoor, Zonneveld \& Macho, 1993; Abel et al., 2012). Either of these problems hinders and might even entirely preclude the segmentation of the fossil, thus preventing the extraction of essential paleobiological evidence (e.g., Schwarz, Vontobel, Lehmann, Meyer, \& Bongartz, 2005; Smith et al., 2009; Zanolli et al., 2017a). For these reasons, an alternative to X-ray $\mu \mathrm{CT}$ is needed. Neutron radiography and tomography, respectively developed in the 1950s and 1970s (Kardjilov et al., 2003; Schwarz et al., 2005; Winkler, 2006), constitute a potential alternative. However, so far neutron-based $\mu \mathrm{CT}(\mathrm{n}-\mu \mathrm{CT})$ has only sporadically been used in paleontological and paleoanthropological research (Schwarz et al., 2005; Sutton, 2008; Zanolli et al., 2013, 2017a; Beaudet et al., 2016; Laaß \& Kaestner, 2017; Schillinger, 2017)., Although the reliability of $n-\mu C T$ for investigating the internal anatomy of fossils has previously been demonstrated by previous researchers (Schwarz et al., 2005; Beaudet et al., 2016; Zanolli et al., 2017a), here we test further the applicability of this method to specimens that cannot be properly analyzed by means of X-ray $\mu \mathrm{CT}$. In particular, by focusing on the fossil remains of two European Miocene catarrhines, we address two common problems in CT-based paleoprimatological research: difficulties in discriminating 
fossilized cranial bone from the surrounding or embedding matrix (as exemplified by the putative stem hominoid Pliobates); and the inability to discriminate well between enamel and dentine in fossil teeth (exemplified by the pliopithecoid Barberapithecus).

\section{2 | MATERIALS AND METHODS}

\section{1 | Studied sample}

The remains of two Miocene catarrhines from the Vallès-Penedès Basin (NE Iberian Peninsula), housed at the Institut Català de Paleontologia Miquel Crusafont (Sabadell, Spain; ICP), were investigated: (1) the partial cranium of Pliobates cataloniae (IPS58443.1, holotype), a putative stem hominoid from the stratigraphic series of Abocador de Can Mata (ACM) locality ACM/C8-A4 (Alba et al., 2015: Figs. 1, 4), with an estimated age of $11.6 \mathrm{Ma}$ (middle to late Miocene boundary; Alba, Casanovas-Vilar, Garcés, \& Robles, 2017); and (2) two lower molars (right $\mathrm{M}_{2}$ and left $\mathrm{M}_{3}$ ) of a single individual of Barberapithecus huerzeleri (respectively IPS1724n,o, holotype), a pliopithecoid from Castell de Barberà (Alba \& Moyà-Solà, 2012: Figs. 4F-G, 5D, 10D-I, $12 \mathrm{~F}, 13 \mathrm{C}$ ), with an estimated age of 11.2-10.3 Ma (late Miocene; Casanovas-Vilar et al., 2016). These specimens are part of the holotypes of their respective species, that of Pliobates consisting of a partial skeleton, and that of Barberapithecus consisting of associated upper and lower teeth of a single individual. The former is thus far the only known individual of this species, which represents the only small-bodied ape currently known from the Miocene of Europe (Alba et al., 2015), whereas the hypodigm of Barberapithecus is restricted to two additional isolated teeth and a fragment o radius from its type locality (Alba \& Moyà-Solà, 2012; Moyà-Solà, Alba, \& Almécija, 2013). The cranium of Pliobates consists of two main parts that are very crushed but not plastically deformed, enabling the virtual reconstruction of its external appearance based on X-ray 
$\mu \mathrm{CT}$ scanning. However, the poor discrimination between cranial bone and the embedding matrix precludes a clear ascertainment of the morphology of inner cranial structures such as the carotid canal, which in Pliobates apparently displays an orientation uniquely shared with extant hylobatids (Alba et al., 2015). In turn, the teeth of Barberapithecus are well preserved; however, unlike for other Vallès-Penedès pliopithecoids (Zanolli et al., 2017b), standard X-ray $\mu \mathrm{Ct}$ do not enable to adequately discriminate between enamel and dentine. This precludes ascertaining the endostructural dental morphology —in particular, the enamel-dentin junction (EDJ) morphology—or to compute 3D relative enamel thickness in this taxon, with potential implications for further clarifying its taxonomic/phylogenetic affinities as well as its paleodietary adaptations, respectively.

\section{2 | Neutron-based computed microtomography}

Radiographic contrast is generated using the attenuation and scattering of a beam that passes through an object. The main difference between X-ray and neutron-based tomography lies on the particles that interact with matter (photons produced by the kinetic variation of the electrons in the former, and neutrons in the latter). X-rays and synchrotron radiation interact with the electron cloud that surrounds the atoms, and thus are more scattered or attenuated by elements possessing a large number of electrons. Being uncharged, neutrons only interact with the nuclei via very short-range forces (Schwarz et al., 2005). The probability of absorption depends on the number of nucleons, thus showing major differences between neighboring elements or even isotopes of the same element (Schillinger, 2017). The attenuation coefficient of X-rays rises monotonously with the number of protons of the elements, while neutrons show a decreasing trend (Schillinger, 2017). This allows high penetration power for heavy mineral elements, which are commonly present in paleontological specimens (Beaudet et al., 2016). On the other hand, neutrons are strongly scattered by hydrogen and some other light elements, such that 
hydrogen-rich materials (i.e., organic materials, glues and resins) are easily detected (Schwarz et al., 2005; Winkler, 2006; Schillinger, 2017).

Most samples become activated if irradiated with neutrons. The standard decay time for the radioactivity ranges between some days and few weeks, after which the specimens can be released (Schillinger, 2017; Schulz et al., 2017). In addition, specific elements (such as europium and cobalt) may achieve hazardous levels of radioactivity if activated by the neutron beam (Sutton, 2008). However, this issue can be easily avoided by running preliminary tests of short-time irradiation and consecutive gamma scan (Schillinger, 2017).

Even if both X-ray and neutron-based radiography produce a shadow image of the sample, the beams used for the analysis differ considerably. X-ray tubes generate a cone beam that magnifies the projection of the sample, while a neutron beam is approximately parallel and does not magnify (Schillinger, 2017). The quality of the image thus depends on the collimation ratio and on the distance between the detector and the sample, while the limit for the resolution of a parallel beam is constrained by the detector's resolution. Using thinned detector screens $(5-20 \mu \mathrm{m})$, a resolution of $10-20 \mu \mathrm{m}$ is achieved (Schillinger, 2017; Schulz et al., 2017).

\section{3 | Scanning settings}

The dimensions and scanning parameters for the studied samples have bee reported in Table 1. They were scanned with $n-\mu C T$ at the imaging facility ANTARES, which is located at the cold neutron beam port of the reactor of the Forschungs-Neutronenquelle Heinz Maier-Leibnitz (FRM II; Garching bei München, Germany). It allows different detector positions and two different chambers, according to the requirements of the sample size, beam size, neutron flux and spatial resolution (for the specifics of the facility, see Schulz et al., 2017). Specimens were placed in chamber two, on a XY-Phi-table with an additional high precision 5-axes HUBER table. Measurements were carried out using the parallel 
neutron beam originated from the cold source of the FRM II reactor with an energy range of 3-25 meV and a collimation ratio of 500. Three different scans were obtained for IPS58443.1: a general one (877 projections for 2,400 slices) with a final isotropic voxel size of $19.90 \mu \mathrm{m}$; and two close-ups, for the temporal (1,105 projections for 2,518 slices) and maxillary (876 projections for 2,486 slices) areas, with a voxel size of $14.22 \mu \mathrm{m}$. In turn, due to the reduced size of the specimens $(<1 \mathrm{~cm})$, IPS1724n,o were scanned with a single cumulative acquisition (2,221 slices) that yielded a final isotropic voxel size of 17.98 $\mu \mathrm{m}$. The histograms of the images stacks were computed with Fiji (Schindelin et al., 2012). X-ray $\mu$ CT were performed for the same specimens. IPS58443.1 was scanned at the American Museum of Natural History (New York, USA) using a Phoenix v|tome|x s180 system, using $160 \mathrm{kV}$ voltage, $1.4 \mathrm{~mA}$ current, $0.2 \mathrm{~mm}$ Cu filter, and magnification of 2.10, obtaining 1,600 slices (virtual cross-sectional images) of $0.2 \mathrm{~mm}$ in thickness and a pixel size of $95.23 \mu \mathrm{m}$. In turn, IPS1724n,o were scanned in a single acquisition at the TomoLab of the Multidisciplinary Laboratory of the International Centre for Theoretical Physics (Trieste; ICTP), with $13 \mathrm{kV}$ voltage, $72 \mu \mathrm{A}$ current, and a $1 \mathrm{~mm}$ Al filter, obtaining 1800 slices and a voxel size of $7.56 \mu \mathrm{m}$.

\section{3 | RESULTS}

The resulting images of $\mathrm{X}$-rays and neutron radiography are very different. Standard radiography provides sharper air-specimen boundaries and uniform dark background, whereas neutron radiography shows more diffuse background noise, especially for IPS58443.1, probably due to the presence of the acrylic resin (Paraloid ${ }^{\circledR} \mathrm{B} 72,5 \%$ diluted in acetone) and nitrocellulosic glue (Imedio ${ }^{\circledR}$ Banda Azul) used in the preparation process. However, the contrast provided by X-ray $\mu$ CT for IPS58443.1 is insufficient to perform an accurate analysis of the internal anatomy. 
The partial cranium of Pliobates is filled with a mudstone matrix that is firmly stuck to the fossilized tissues and was only partially removed during the preparation process. Electrondense elements fill some of the fractures along the specimen or are found dispersed in the sediment, resulting in bright spots on the images stack that led to the underexposure of the radiographies. The histograms calculated for the whole images stack show a low-shifted distribution of the intensity curve with two extremely steep peaks (Fig. 2E). The lowest one belongs to the air background, while the other includes both sediment and fossilized bone. Due to the spot-like accumulation of the denser minerals, their peak is diluted within the histogram and becomes visible only when cropping the image to the exact region of the bright spots. Even if contrast is very low, segmentation between outer sediment and fossilized tissues is possible (Alba et al., 2015). However, contrast is insufficient to properly discern the inner matrix from internal bone boundaries of cranial cavities (Fig. $1 E)$, especially close to the bright spots. In contrast, $n-\mu C T$ produced more balanced images (Fig. 1F). This is clearly visible in the distribution of the intensities in the histograms (Fig. 2F), where the second peak (corresponding to the embeddingsediment/fossilized tissues compound) is lower and more distributed along the intensity axis. The fossilized tissues appear in lighter gray, as the permineralization process is likely not complete (or affects different areas of the fossil in a differential way) and their mineral composition still differs from the embedding matrix, which appears darker and richer in heavy elements (Fig. 1F). This enables the distinction and manual segmentation of the borders of the inner cavities, such as the bony labyrinth, the inner ear nerves, or the carotid canal, inter alia.

The two molars of Barberapithecus (IPS1724n,o) appear as a uniform gray-to-white mass in the X-ray scans, such that there is no discernible EDJ (Fig. 1A,C). Probably this is the result of deep mineralization of the dentine during the fossilization process, which caused it to converge in chemical composition with the enamel. The histograms calculated 
233 for each tooth, on the whole slices stack (Fig. 2A,C), show that there is a shift of the 234 intensity curve towards higher intensity values for the standard X-ray $\mu \mathrm{CT}$ images stacks. 235 The right end of the curve shows a peak that corresponds to the brighter areas of the dentine, in which elements with a high attenuation coefficient have penetrated. The steep black background peak occupies the lowest intensity range. These two peaks flank a lower one (ranging from ca. 155 to 240 of the grayscale) that corresponds to the enamel-dentine compound, visible as an indistinct gray to white mass (Fig. 1A,C). In contrast, $n-\mu C T$ images stacks have more balanced histograms, in which the dental tissues (i.e., dentine and enamel) are better differentiated (Fig. 2B,D). Apart from broader lower peak, due to a lighter background, the curves displays a different intensity for the enamel (darker) and the dentine (lighter). Inside the pulp cavity, the presence of lighter and hydrogen-rich minerals in the two molars (Fig. 1B,D) locally produces some noise (clearly visible in the histogram as an anomalous peak at the very end of the color map). However, it does not affect contrast in the EDJ, enabling the manual segmentation of enamel and dentine, and therefore a correct identification of the former (Fig. 3).

\section{4 | DISCUSSION}

Our results indicate that $\mathrm{n}-\mu \mathrm{CT}$ provides a higher anatomical resolution for two specimens, whose internal anatomy could not be adequately segmented by means of X-ray $\mu \mathrm{CT}$ scans, due to several problems: an extreme similarity between the chemical composition of the matrix and that of the fossilized tissues (in the cranium of Pliobates); a high similarity between the chemical composition of different fossilized tissues (in the molars of Barberapithecus); and the presence of high-density elements (in the cranium of Pliobates). Standard X-ray and synchrotron radiation $\mu \mathrm{CT}$ are preferable because of the greater sharpness of the images, the lack of activation, and the availability of the facilities in the case of the former. However, $\mathrm{n}-\mu \mathrm{CT}$ provides a better contrast of different isotopes of the 
same element and more easily penetrates metals than X-ray $\mu \mathrm{CT}$. These advantages provide a better definition of the bone/sediment boundary and between different dental tissues, thereby enabling a better segmentation of the images stack in fossils that are problematic with standard $\mu \mathrm{CT}$. The complementarity of the contrasts obtained by $\mathrm{n}-\mu \mathrm{CT}$ and its enhanced penetration power are particularly indicated for thick and heavy-element rich fossil material-two conditions that are commonly found in paleontological specimens. We therefore conclude that neutron radiation represents an accessible and successful alternative to X-rays for the $\mu \mathrm{CT}$ of fossil specimens when the latter fail to obtain the desired outcome.

\section{ACKNOWLEDGEMENTS}

We thank Marta S. March and Jordi Galindo for assistance in collection managing, and J. Thostenson and M. Hill for assistance with using the Microscopy and Imaging Facility of the American Museum of Natural History. This work has been supported by the Spanish Ministerio de Economía, Industria y Competitividad and the European Regional Development Fund of the European Union (MINECO/FEDER EU, project CGL201454373-P), the Spanish Agencia Estatal de Investigación and the European Regional Development Fund of the European Union (AEI/FEDER EU, project CGL2016-76431-P), and the Generalitat de Catalunya (CERCA Programme). We are also grateful to an annonymous reviewer for constructive comments that helped us to improve a previous version of this paper.

\section{REFERENCES}

Abel, R. L., Rettondini Laurini, C., \& Richter, M. (2012). A palaeobiologist's guide to 'virtual' micro-CT preparation. Palaeontologia Electronica, 15, 15.2.6T. 
Alba, D. M., \& Moyà-Solà, S. (2012). A new pliopithecid genus (Primates: Pliopithecoidea) from Castell de Barberà (Vallès-Penedès Basin, Catalonia, Spain). American Journal of Physical Anthropology, 147, 88-112.

Alba, D. M., Almécija, S., DeMiguel, D., Fortuny, J., Pérez de los Ríos, M., Pina, M., Robles, J. M., \& Moyà-Solà S. (2015). Miocene small-bodied ape from Eurasia sheds light on hominoid evolution. Science, 350, aab2625.

Alba, D. M., Casanovas-Vilar, I., Garcés, M., \& Robles, J. M. (2017). Ten years in the dump: An updated review of the Miocene primate-bearing localities from Abocador de Can Mata (NE Iberian Peninsula). Journal of Human Evolution, 102, 12-20.

Beaudet, A., Braga, J., de Beer, F., Schillinger, B., Steininger, C., Vodopivec, V., \& Zanolli, C. (2016). Neutron microtomography-based virtual extraction and analysis of a cercopithecoid partial cranium (STS 1039) embedded in a breccia fragment from Sterkfontein Member 4 (South Africa). American Journal of Physical Anthropology, 159, 737-745.

Benazzi, S., Kullmer, O., Schulz, D., Gruppioni, G., \& Weber, G. W. (2013). Technical note: Individual tooth macrowear pattern guides the reconstruction of Sts 52 (Australopithecus africanus) dental arches. American Journal of Physical Anthropology, 150, 324-329.

Benazzi, S., Gruppioni, G., Strait, D. S., \& Hublin, J. J. (2014). Technical note: Virtual reconstruction of KNM-ER 1813 Homo habilis cranium. American Journal of Physical Anthropology, 153, 154-160.

Casanovas-Vilar, I., Garcés, M., Van Dam, J., García-Paredes, I., Robles, J. M., \& Alba, D. M. (2016). An updated biostratigraphy for the late Aragonian and the Vallesian of the Vallès-Penedès Basin (Catalonia). Geologica Acta, 14, 195-217. 
Cunningham, J. A., Rahman, I. A., Lautenschlager, S., Rayfield, E. J., \& Donoghue, P. C. J. (2014). A virtual world of paleontology. Trends in Ecology and Evolution, 29, 347357.

Faulwetter, S., Vasileiadou, A., Kouratoras, M., Dailianis, T., \& Arvanitidis, C. (2013). Micro-computed tomography: Introducing new dimensions to taxonomy. Zookeys, 263, 1-45.

Gren, J. A., Sjövall, P., Eriksson, M. E., Sylvestersen, R. L., Marone, F., Sigfridsson Clauss, K. G. V., Taylor, G. J., Carlson, S., Uvdal, P., \& Lindgren, J. (2016). Molecular and microstructural inventory of an isolated fossil bird feather from the Eocene Fur Formation of Denmark. Palaeontology, 60, 73-90.

Kardjilov, N., Baechler, S., Bastürk, M., Dierick, M., Jolie, J., Lehmann, E., Materna, T., Schillinger, B., \& Vontobel, P. (2003). New features in cold neutron radiography and tomography Part II: applied energy-selective neutron radiography and tomography. Nuclear Instruments and Methods in Physics Research Section A: Accelerators, Spectrometers, Detectors and Associated Equipment, 501, 536-546.

Laaß, M., \& Kaestner, A. (2017). Evidence for convergent evolution of a neocortex-like structure in a late Permian therapsid. Journal of Moprhology, 278, 1033-1057.

Lautenschlager, S. (2016). Reconstructing the past: methods and techniques for the digital restoration of fossils. Royal Society Open Science, 3, 160342.

Macchiarelli, R., Bondioli, L., Falk, D., Faupl, P., Illerhaus, B., Kullmer, O., Richter, W., Hasen, S., Sandrock, O., Schäfer, K., Urbanek, C., Viola, B. T., Weber, G. W., \& Seidler, H. (2004). Early Pliocene hominid tooth from Galili, Somali Region, Ethiopia. Collegium Antropologicum, 28 Suppl. 2, 65-76.

Macchiarelli, R., Bayle, P., Bondioli, L., Mazurier, A., \& Zanolli, C. (2013). From outer to inner structural morphology in dental anthropology: integration of the third dimension in the visualization and quantitative analysis of fossil remains. In G. R. Scott \& J. D. 
Irish (Eds.), Anthropological perspectives on tooth morphology: Genetics, evolution, variation (pp. 250-277). Cambridge: Cambridge University Press.

Moyà-Solà, S., Alba, D. M., \& Almécija, S. (2013). A proximal radius of Barberapithecus huerzeleri (Primates, Pliopithecidae) from the Miocene site of Castell de Barberà (NE Iberian Peninsula). Journal of Vertebrate Paleontology, 33 Suppl. 2, 182.

Olejniczak, A. J., \& Grine, F. E. (2006). Assessment of the accuracy of dental enamel thickness measurements using microfocal X-ray computed tomography. Anatomical Record A, 288, 263-275.

Olejniczak, A. J., Tafforeau, P., Temming, H., Smith, T. M., \& Hublin, J.-J. (2007). Technical note: compatibility of microtomographic imaging systems for dental measurements. American Journal of Physical Anthropology, 134, 130-134.

Schindelin, J., Arganda-Carreras, I., Frise, E., Kaynig, V., Longair, M., Pietzsch, T., Preibisch, S., Rueden, C., Saalfeld, S., Schmid, B., Tinevez, J., White, D. J., Hartenstein, V., Eliceiri, K., Tomancak, P., \& Cardona, A. (2012). Fiji: an open-source platform for biological-image analysis. Nature Methods, 9, 676-682.

Schillinger, B. (2017). Why use neutrons? Restaurierung und Archäologie, 8, 1-7.

Schulz, M., Schillinger, B., Calzada, E., Bausenwein, D., Schmakat, P., Reimann, T., \& Böni, P. (2017). Die neue Anlage ANTARES für Neutronenbildgebung am FRM II. Restaurierung und Archäologie, 8, 9-14.

Schwarz, D., Vontobel, P., Lehmann, E. H., Meyer, C. A., \& Bongartz, G. (2005). Neutron tomography of internal structures of vertebrate remains: A comparison with X-ray computed tomography. Palaeontologia Electronica, 8, 8.2.30A.

Smith, T. M., Olejniczak, A. J., Kupczik, K., Lazzari, V., de Vos, J., Kullmer, O., Schrenk, F., Hublin, J. J., Jacob, T., \& Tafforeau, P. (2009). Taxonomic assessment of the Trinil molars using nondestructive 3D structural and development analysis. PaleoAnthropology, 2009, 117-129. 
Spoor, C. F., Zonneveld, F. W., \& Macho, G. A. (1993). Linear measurements of cortical bone and dental enamel by computed tomography: applications and problems. American Journal of Physical Anthropology, 91, 469-484.

Sutton, M. D. (2008). Tomographic techniques for the study of exceptionally preserved fossils. Proceedings of the Royal Society B, 275, 1587-1593.

Tuniz, C., Bernardini, F., Cicuttin, A., Crespo, M. L., Dreossi, D., Gianoncelli, A., Macini, L., Mendoza Cuevas, A., Sodini, N., Tromba, G., Zanini, F., \& Zanolli, C. (2013). The ICTP-Elettra X-ray laboratory for cultural heritage and archaeology. Nuclear Instruments and Methods in Physics Research Section A: Accelerators, Spectrometers, Detectors and Associated Equipment, 711, 106-110.

Winkler, B. (2006). Applications of neutron radiography and neutron tomography. Reviews in Mineralogy and Geochemistry, 63, 459-471.

Zanolli, C., Grine, F.E., Kullmer, O., Schrenk, F., \& Macchiarelli, R. (2015). The Early Pleistocene deciduous hominid molar FS-72 from the Sangiran Dome of Java, Indonesia: A taxonomic reappraisal based on its comparative endostructural characterization. American Journal of Physical Anthropology, 157, 666-674.

Zanolli, C., Mancini, L., Kullmer, O., Macchiarelli, R., Rook, L., Schillinger, B., Schrenk, F., Tuniz, C., \& Vodopivec, V. (2013). Problems and limitations of X-ray microtomography for the endostructural characterization of fossil tooth tissues. In B. Schillinger (Ed.), NINMACH 2013. 1st International Conference on Neutron Imaging and Neutron Methods in Archaeology and Cultural Heritage Research. Abstract booklet (pp. 56-57). Garching bei München: Technische Universität München.

Zanolli, C., Schillinger, B., Beaudet, A., Kullmer, O., Macchiarelli, O., Mancini, L., Schrenk, F., Tuniz, C., \& Vodopivec V. (2017a). Exploring hominin and non-hominin primate dental fossil remains with neutron microtomography. Physics Procedia, 88, 109-115. 
385 Zanolli, C., Alba, D. M., Dean, M. C., Fortuny, J., Macchiarelli, R., \& Rook, L. (2017b). Oreopithecus bambolii is still an "enigmatic anthropoid". American Journal of Physical Anthropology, 162 S64, 420. 
TABLE 1 List of the studied specimens, including dimensions and scanning parameters.

\begin{tabular}{cccccc}
\hline Specimen & ML & MW & VxS-X & VxS-N & FoV \\
\hline IPS58443.1 & 66.0 & 49.9 & 68.22 & 19.895524 & $42.97 \times 47.75$ \\
Maxilla zoom & & & & 14.215323 & $30.71 \times 35.79$ \\
Inner ear zoom & & & 14.215323 & $30.71 \times 35.34$ \\
IPS1724n & 6.31 & 5.15 & 7.56 & 17.381885 & $20.04 \times 38.64$ \\
IPS17240 & 6.99 & 4.94 & 7.56 & 17.381885 & $20.04 \times 38.64$ \\
\hline
\end{tabular}

Abbreviations: FoV-X, field of view (mm x mm) of $n-\mu C T$; ML, maximum length $(\mathrm{mm})$; MW, 388 maximum width (mm); VxS-N, n- $\mu C T$ voxel size $(\mu \mathrm{m})$; VxS-X, X-ray $\mu \mathrm{CT}$ voxel size $(\mu \mathrm{m})$. 


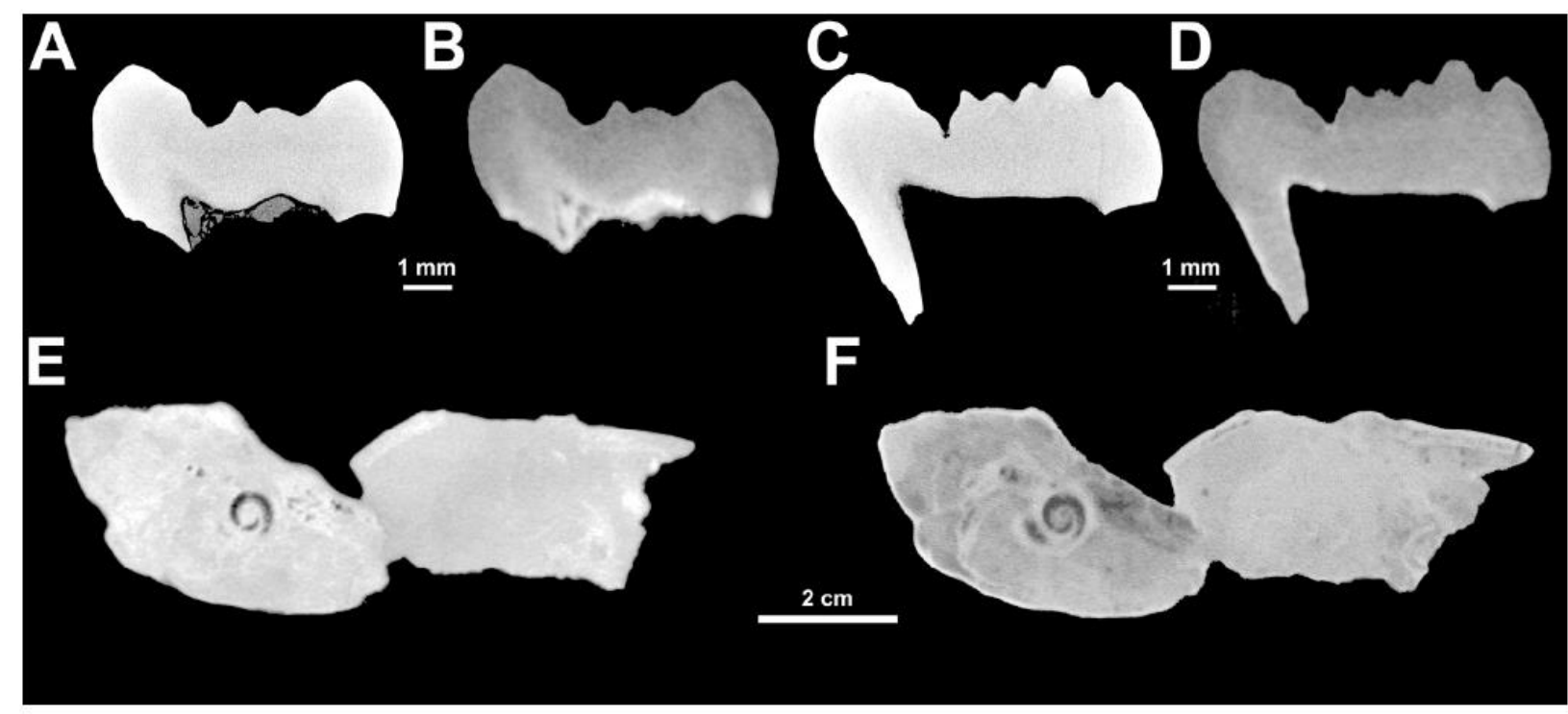

390 FIGURE 1 Selected images of X-ray and neutron microcomputed tomography $(\mu \mathrm{CT})$ of two 391 Barberapithecus molars (IPS1724n,o) and the Pliobates cranium (IPS58443.1). (A-B)

392 Cross-section of IPS1724n through the metaconid and hypoconulid, based on X-ray (A)

393 and neutron (B) $\mu \mathrm{CT}$. (C-D) Cross-section of IPS17240 through the protoconid and 394 hypoconulid, based on X-ray (C) and neutron (D) $\mu$ CT. (E-F) Cross-section of IPS58443.1 395 through the petrosal bone, based on X-ray (E) $\mu \mathrm{CT}$ and neutron $(F) \mu C T$. Note: the 396 sections compared differ slightly due to different slice thickness. 

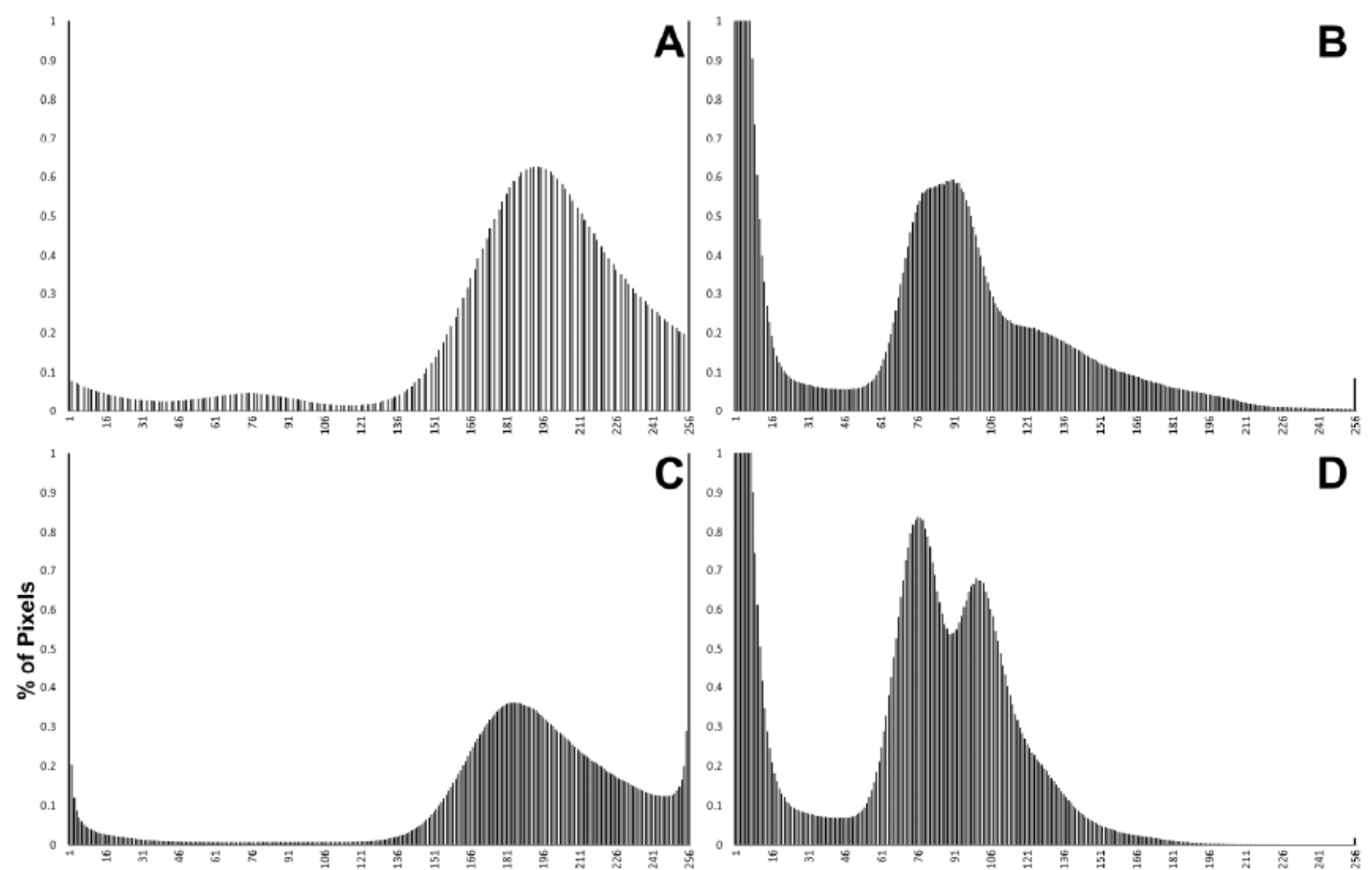

398

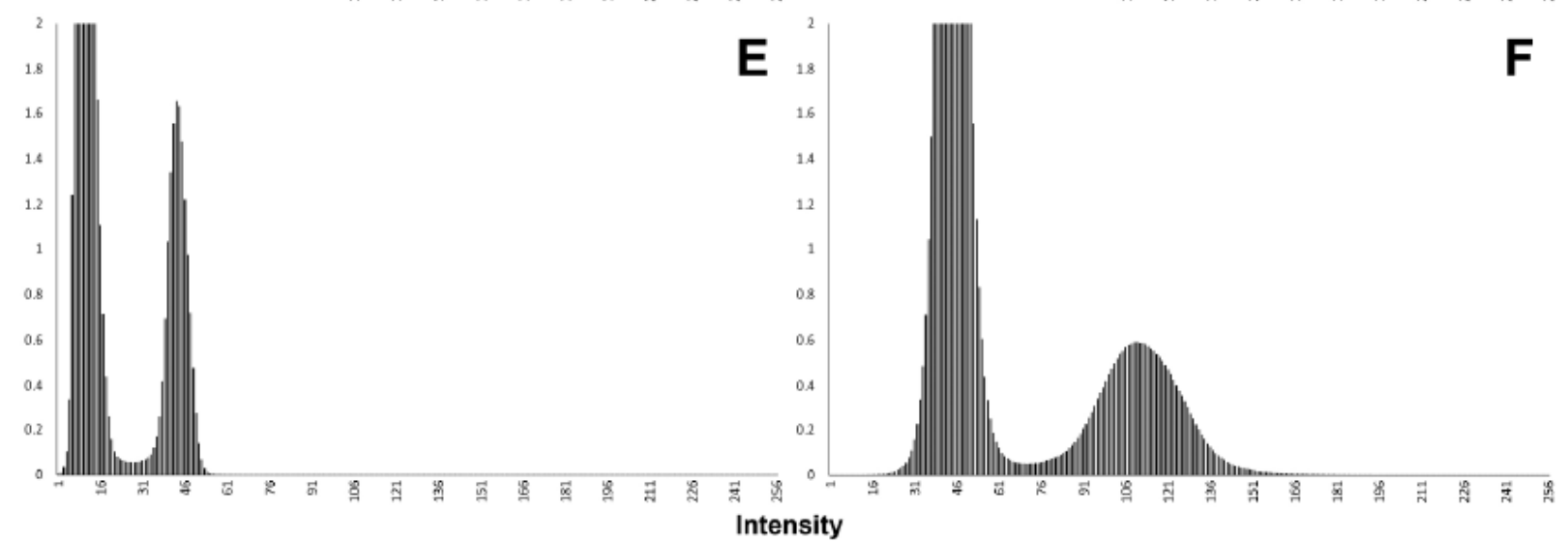

399 FIGURE 2 Whole images stack histograms from different sources: (A) X-ray

400 microcomputed tomography ( $\mu$ CT? of IPS1724n; (B) neutron $\mu C T$ of IPS1724n; (C) X-ray

$401 \mu C T$ of IPS17240; (D) neutron $\mu C T$ of IPS17240; (E) X-ray $\mu C T$ of IPS58443.1; (F) neutron $402 \mu \mathrm{CT}$ of IPS58443.1. 


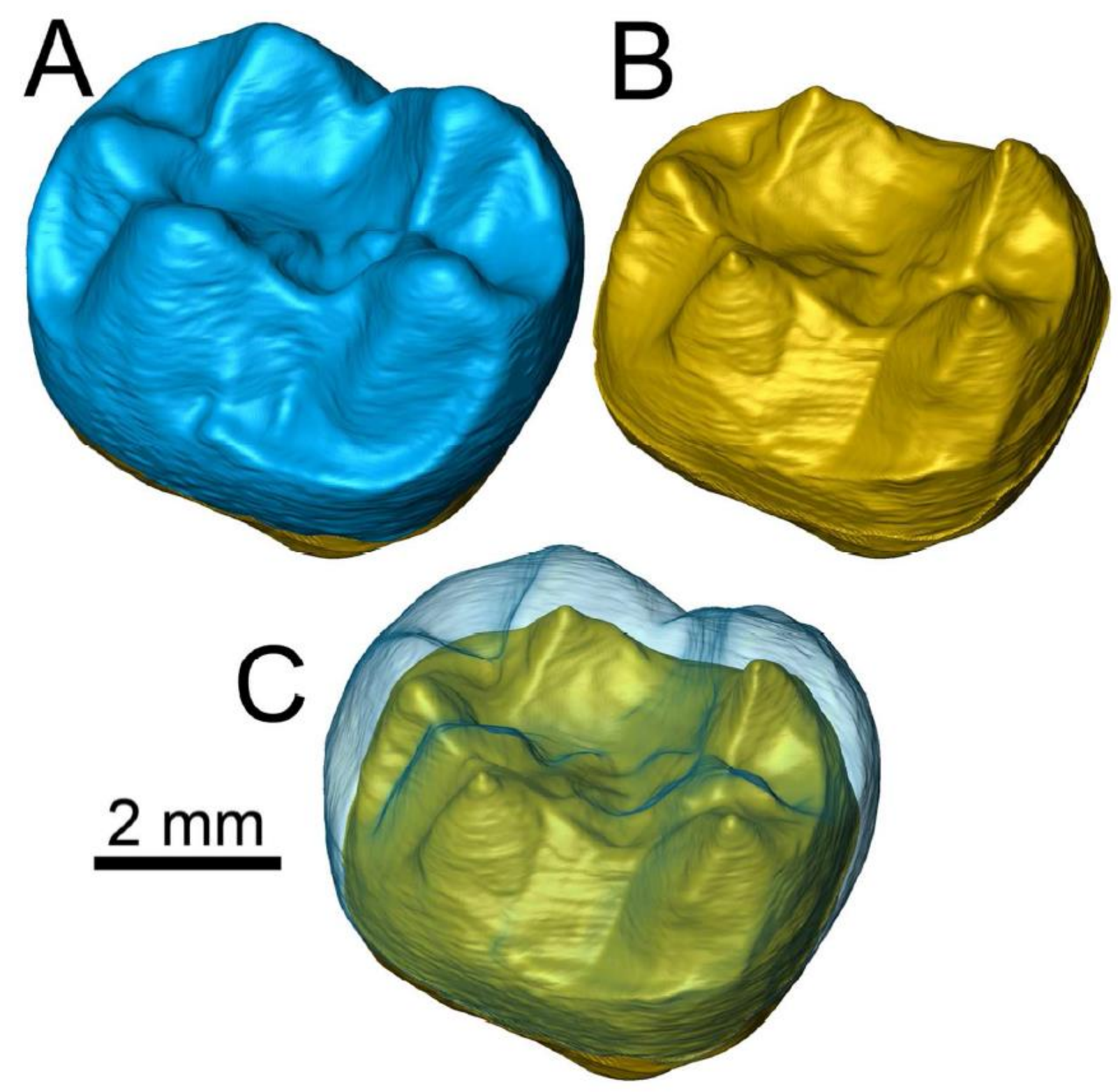

405 FIGURE 3 Virtually reconstructed right M2 of Barberapithecus huerzeleri (IPS1724n)

406 based on neutron microcomputed tomography ( $\mu \mathrm{CT})$ scans, in oblique (semiocclusal and 407 mesiobuccal) view: (A) external morphology (enamel surface); (B) inner morphology 408 (enamel-dentine junction, EDJ); (C) enamel surface superimposed in semitransparency to 409 the EDJ. 